\title{
The Two Faces of Lactobacillus kunkeei: Wine Spoilage Agent and Bee Probiotic
}

Linda F. Bisson, ${ }^{1{ }^{*}}$
Gordon Walker, ${ }^{1}$
Vidhya
Ramakrishnan, ${ }^{1}$
Yan Luo, ${ }^{1}$
Qingwen Fan, ${ }^{1}$
Emily Wiemer, ${ }^{1}$
Peter Luong, ${ }^{1}$
Minami Ogawa, ${ }^{1}$
and Lucy Joseph ${ }^{1}$
Cite this article:
Bisson LF, Walker G,
Ramakrishnan V, Luo $Y$,
Fan Q, Wiemer E, Luong
P, Ogawa M and Joseph
L. 2017. The two faces
of Lactobacillus kunkeii:
Wine spoilage agent and
bee probiotic. Catalyst
1:1-11.

${ }^{1}$ Department of Viticulture and Enology, University of California, Davis, One Shields Ave, Davis, CA 95616.

*Corresponding author (lfbisson@ucdavis.edu; tel: 530-752-3835; fax: 530-752-0382)

Manuscript submitted Mar 2016, revised May 2016, accepted Jun 2016

Copyright (c) 2017 by the American Society for Enology and Viticulture. All rights reserved. doi: $10.5344 /$ catalyst.2016.16002

\section{Summary}

Importance: Lactobacillus kunkeei, also known as the "ferocious lactobacilli", causes fermentation arrest during wine production ${ }^{1}$. L. kunkeei co-evolved with honeybees and is an important probiotic for bee and hive health ${ }^{2}$. In the bee ecosystem, L. kunkeei is one of a suite of lactic acid bacteria that protect the bee and hive from pathogens as well as aid in preservation of sugar-rich hive resources. The protection of sugar-rich resources probably uses similar mechanisms to those inhibiting yeast during grape juice fermentation.

\section{Key Observations:}

- The probiotic role of L. kunkeei

- Unique aspects of $L$. kunkeei metabolism enabling rapid growth in grape juice

- Proposed mechanisms of inhibition of yeast fermentation by L. kunkeei

- The environmental incentive for $\left[G A R^{+}\right]$prion induction by yeast in the presence of $L$ kunkeei and fermentation arrest

Impact and Significance: The essential role of L. kunkeei in prevention of bee colony collapse disorder limits the options available to winemakers for control of this pervasive spoilage agent. L. kunkeei can be controlled by sulfur dioxide $\left(\mathrm{SO}_{2}\right)$ addition ${ }^{3}$. However, although this organism is sensitive to $\mathrm{SO}_{2}$, our data suggest that other microbes present in juice at the same time may reduce the effective concentration of $\mathrm{SO}_{2}$, thereby enabling growth of L. kunkeei. Clues from the mechanism of arrest of fermentation may help explain the role of $L$. kunkeei in bee health.

Key words: acetic acid bacteria, fermentation arrest, $\left[G A R^{+}\right]$prion, Lactobacillus kunkeei

\section{Overview}

The existence of "ferocious lactobacilli" has been recognized for some time". These lactic acid bacteria proliferate quickly in grape juice and rapidly produce high levels of acetic acid, attaining levels normally found only within the acetic acid bacteria ${ }^{3}$. The amount of acetic acid produced is inhibitory to fermentation progression $^{4}$. One of these types of lactic acid bacteria was isolated from wine, identified as a new species, and named Lactobacillus kunkeei ${ }^{5}$. L. kunkeei has been shown to be present in vineyards and comes in on the grapes at harvest, generally at low population numbers ${ }^{6}$. Since this organism can grow efficiently in grape juice, the population increases significantly within the first few days ${ }^{7}$. The natural habitat of L. kunkeei is the honeybee gastrointestinal tract, and this organism is particularly dominant in the foregut or crop of the bee ${ }^{8}$. Thus, honeybees present in vineyards are probable vectors of $L$. kunkeei. It is also possible that bees present around grapes at harvesting, if accidentally processed along with the fruit and crushed, could release L. kunkeei to the juice or must, but this has not been investigated.

Given the economic impact of loss of managed bee populations due to colony collapse disorder $(\mathrm{CCD})^{9}$ there is much scientific interest in determining 
the mechanisms by which honeybees normally resist pathogen invasion and hive decline. The cause of the widespread CCD phenomenon is not known precisely, but factors that have been implicated include transport stress, hive accumulation of agrochemicals, presence of mites, presence of pathogens, and lack of resistance or immunity toward those pathogens ${ }^{10}$. Analysis of the honeybee microbiome revealed a highly-conserved population of largely lactic acid bacteria ${ }^{11}$. The same profile of bee-associated microbes was found in bees worldwide and across bee species, suggesting an early co-evolution of honeybees and these bacterial symbionts $^{11}$. Approaches to forestall collapse of hives such as use of antibiotics against larval pathogens have been met with limited success ${ }^{12}$.

Subsequent research has shown that the community of microorganisms associated with honeybees, hives, and bee products plays an important role in minimizing or inhibiting the growth of deleterious microbes both within the bee and in hive food sources ${ }^{13}$. The failure of antimicrobial agents targeting bee pathogens to stabilize hives against CCD is likely due to the simultaneous inhibition of beneficial microbes. Thirteen microbial species or subtypes are commonly found associated with healthy hives ${ }^{14}$. L. kunkeei is the dominant species commonly isolated across these analyses. Each of these 13 organisms has been evaluated for their ability to inhibit the growth of bee pathogens, as well as environmental organisms including yeast, that could easily use hive food sources as growth substrates ${ }^{15}$. The greatest levels of inhibition of target bacteria or yeast are seen when a combination of these organisms are present, suggesting that the bacteria collectively possess a broad array of inhibitory characteristics ${ }^{16}$. When tested individually, L. kunkeei emerged as one of the most inhibitory members of the consortium, particularly toward yeast ${ }^{17}$. In one study that evaluated inhibition of flower and pollen residents including yeast and fungi, L. kunkeei was able to inhibit the growth of both the yeasts and fungi tested, as well as many of the bacteria ${ }^{18}$. Thus, L. kunkeei has evolved to play a major role in inhibition of microbial contaminants of bees and bee products, and its ability to inhibit yeast fermentation of grape juice likely uses similar mechanisms.

\section{Discoveries}

The probiotic role of $\boldsymbol{L}$. kunkeei. It is now generally believed that a primary hive defense against pathogens and bee food spoilage is the creation and maintenance of an actively inhibitory community of microorgan- isms ${ }^{19}$. These microbes enhance the innate immune system of the bee and in combination have the capacity to inhibit the growth of a variety of pathogenic and non-pathogenic organisms. The foraging lifestyle and communal hive habitation characteristics of bees means that potentially deleterious environmental microbes will constantly be introduced to the hive. The role of lactic acid bacteria symbionts in the defense against these detrimental organisms and the pivotal role played by L. kunkeei has only recently become appreciated $^{20}$.

L. kunkeei is found in adult bees and throughout the hive, present in larvae and in larval food or beebread. It is the dominant organism in the crop or foregut where the nectar is stored in the bee for delivery to the hive ${ }^{21}$. This population of L. kunkeei plays a critical role from the onset of bee feeding in protection of sugar-rich nutrient sources. One of the pathogens that can lead to colony collapse is Paenibacillus larvae, which infects bee larvae leading to a high mortality of the larvae ${ }^{22}$. P. larvae is found in hives not undergoing $\mathrm{CCD}^{23}$, suggesting that its proliferation and ability to cause disease is kept in check in the hive. In addition, $P$. larvae can form resistant spores, making it challenging to control using chemical agents compatible with bee hive biota ${ }^{24}$. L. kunkeei has been shown to directly protect larvae from P. larvae in feeding studies, as well as from other pathogens when present in the hive and in hive food sources, and is now recommended to be used in commercial bee foods ${ }^{25}$. Thus, the presence of L. kunkeei and other bacteria within the hive comprise a natural biocontrol system.

Researchers have investigated the factors responsible for the broad-spectrum inhibition of other microbial species by L kunkeei. One important factor is its ability to rapidly produce high levels of acetic and lactic acid which, in combination with formic acid produced by hive resident bifidobacteria, create a high acid/low pH environment ${ }^{26}$. In addition, L. kunkeei and other resident microorganisms make a host of other inhibitory substances ${ }^{27}$. Fatty acids known to be inhibitory to Saccharomyces are also released by L. kunkeei ${ }^{27}$. Inhibitory peptides or proteins are also made as protease treatment of L. kunkeei spent medium reduces, and in some cases, eliminates inhibition of some sensitive bacteria ${ }^{28}$. The array of inhibitory compounds produced by L. kunkeei in natural bee habitats may also be responsible for the inhibition of yeast fermentation.

Unique aspects of $L$. kunkeei metabolism enabling rapid growth in grape juice. L. kunkeei is a 
heterofermentative lactic acid bacterium, meaning that it belongs to the group of lactic acid bacteria that produce acetic acid, ethanol, and lactate as end products of hexose metabolism ${ }^{29}$. This mode of metabolism yields energy when lactic or acetic acid are made, but not when ethanol is produced (Figure 1). Ethanol is formed solely to regenerate oxidized cofactors. During metabolism, the cofactor $\mathrm{NAD}^{+}$is reduced to $\mathrm{NADH}$.

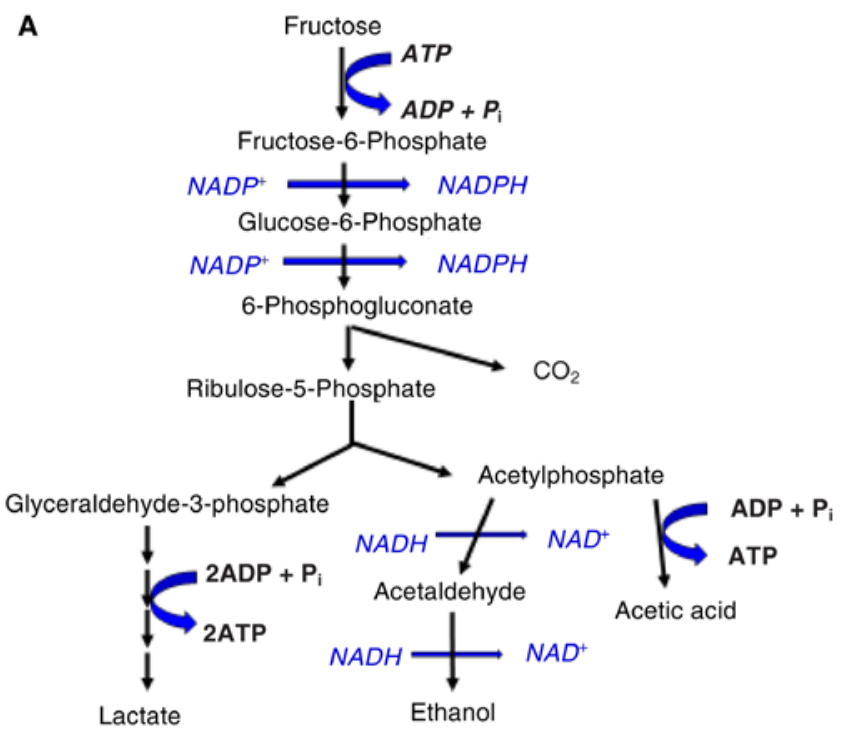

B

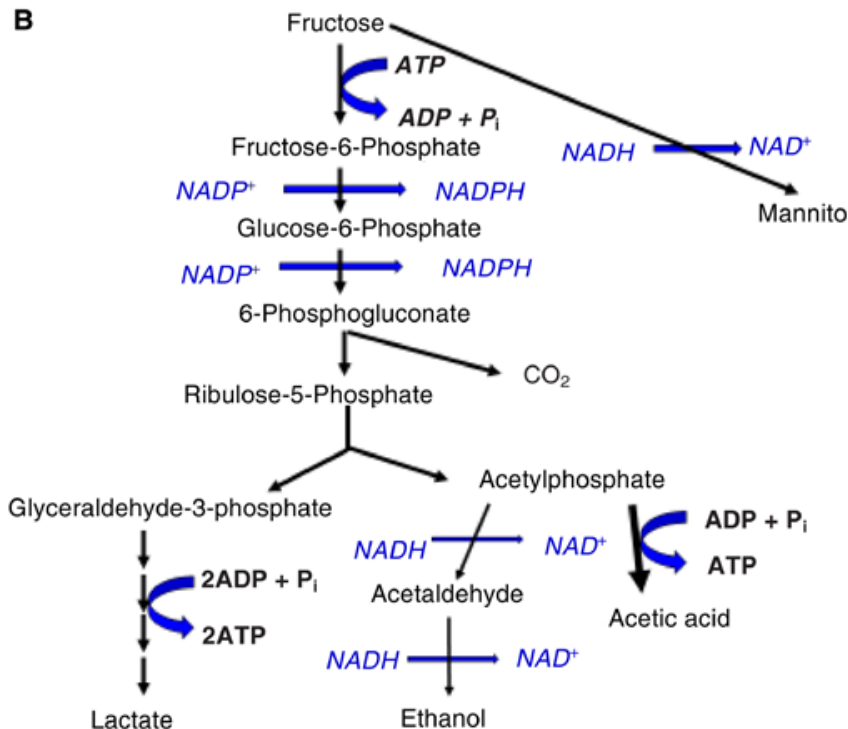

Figure 1 Diagram of the pathway for heterolactic fermentation of fructose by lactic acid bacteria. A: the end products of the pathway are lactic acid, acetic acid, ethanol, and $\mathrm{CO}_{2}$. Energy (ATP) is made in the conversion of glyceraldehyde-3-phosphate to lactate and in the conversion of acetylphosphate to acetic acid. The reduction of acetylphosphate to ethanol regenerates NAD+ from NADH, but is not energy generating. B: fructophilic lactic acid bacteria produce greatly reduced levels of ethanol and instead use the conversion of fructose to its alcohol form mannitol to regenerate NAD+.
$\mathrm{NAD}^{+}$must be regenerated to sustain carbohydrate metabolism. The production of ethanol is a common biological strategy for the regeneration of $\mathrm{NAD}^{+}$from its reduced form NADH via the transfer of an electron from the cofactor to acetaldehyde forming ethanol. Molecular oxygen can also be used to regenerate $\mathrm{NAD}^{+}$, and many heterofermentative lactic acid bacteria will produce high levels of acetic acid and little to no ethanol in the presence of oxygen.

L. kunkeei uses a different mechanism to regenerate $\mathrm{NAD}^{+}$. Analyses of end products formed from sugars showed that L. kunkeei produces more acetic acid and less ethanol than is typical for heterofermentative lactic acid bacteria under anaerobic conditions, but also produced high levels of mannitol when fructose is available $^{30}$. The formation of mannitol from fructose regenerates $\mathrm{NAD}^{+}$, enabling metabolism to continue. $L$. kunkeei is categorized as "fructophilic", meaning that it prefers to utilize fructose over glucose and can do so quickly ${ }^{30}$. Growth of L. kunkeei on glucose requires a co-substrate such as pyruvate perhaps because of the loss of ability to regenerate cofactors via ethanol production ${ }^{30}$. L. kunkeei has evolved to use fructose itself as the agent for regeneration of cofactors, thus explaining its preference for fructose and the formation of mannitol (Figure 1B). Fructose is directly reduced to its alcohol, mannitol, in an equimolar ratio to the consumption of fructose for energy ${ }^{30}$. Thus, growing on fructose in the absence of oxygen, L. kunkeei can produce energy levels equivalent to those of the other heterofermentative lactic acid bacteria growing in the presence of oxygen. This bacterium can grow rapidly in juice simply because of the high fructose content. Because nectar and honey are high in fructose, $L$ kunkeei likely evolved this specialized mode of metabolism as a bee symbiont. However, the initial isolate and strain type of $L$. kunkeei from wine showed a reduced ability to use fructose for cofactor regeneration ${ }^{31}$.

Although found primarily associated with bees, $L$. kunkeei has also been isolated from a variety of sources in nature visited by bees ${ }^{32}$. It was the most dominant fructophilic lactic acid bacterium isolated in a survey of fruits and flowers, and strain differences were observed among the isolates. These findings suggest that there is routine exchange of L. kunkeei between bees and the surfaces they visit. The observations of L. kunkeei on the surfaces of grapes in vineyards is consistent with the primary source and vector of this organism being honeybees.

Proposed mechanisms of inhibition of yeast fermentation by L. kunkeei. Although the existence of 
"ferocious lactobacilli" had been known for decades, these organisms were challenging to isolate and study ${ }^{3}$. Edwards and colleagues succeeded in isolating an inhibitory lactic acid bacterium from stuck and sluggish wines $^{33}$ and subsequently identified it as a new species that they named L. kunkeei ${ }^{34}$. L. kunkeei is able to grow quickly in juice when populations are not kept in check by low $\mathrm{pH}$ and use of $\mathrm{SO}_{2}{ }^{3}$. Because acetic acid is known to be inhibitory to Saccharomyces ${ }^{35}$, the high level of production of acetic acid by L. kunkeei was thought to be the reason for the arrest of fermentation during wine production ${ }^{36}$. L. kunkeei can produce 4 to $5 \mathrm{~g} / \mathrm{L}$ of acetic acid when inoculated into juice ${ }^{36}$. When fermentations were dosed daily with acetic acid to mimic the conditions of production during co-cultivation with L. kunkeei, the level of inhibition of fermentation depended upon the strain used and the starting sugar lev$\mathrm{el}^{36}$. Although acetic acid additions can mimic arrest of fermentation, the kinetics and extent of arrest did not completely match that seen with L. kunkeei. Mannitolproducing heterofermentative lactic acid bacteria also produce n-propanol and 2-butanol ${ }^{37}$, and these substances may also be inhibitory perhaps especially in combination with the high acidity.

The effect of acetic acid on fermentation progression has been investigated and the mechanism of inhibition of fermentation established ${ }^{38}$. The impact of acetic acid is more severe if the exposure to the acid occurs during the growth phase of the yeast ${ }^{39}$. Acetic acid also acts synergistically with ethanol, meaning that fermentation arrest occurs only after a high level of ethanol has developed in the medium ${ }^{38}$. The explanation for this effect is that acetic acid is transported into the cell in a protonated or neutral (uncharged) form, but soon loses a proton within the yeast cell, thus acidifying the cytoplasm ${ }^{38}$. The presence of ethanol increases passive proton entry into the cell. The $\mathrm{pH}$ of the cytoplasm is maintained via the action of the plasma membrane ATPase or proton pump. As fermentation progresses and higher levels of ethanol are present in the environment, the cell struggles to maintain cellular $\mathrm{pH}$ homeostasis in the presence of acetic acid because the capacity of the pump to remove protons becomes saturated. Consequently, fermentation is arrested. Acetic acid, which may have been produced in the juice prior to fermentation, thus does not display an inhibitory effect until the latter stages of fermentation when ethanol is present in high concentration and the capacity of the proton pump becomes saturated. Although protonated or undissociated acetic acid would be present in higher concentrations at lower $\mathrm{pH}$, at higher $\mathrm{pH}$, the membrane is more permeable to undissociated acids, leading to a greater level of inhibition at higher $\mathrm{pH}$ values ${ }^{40}$. Thus, the presence of acetic acid reduces the maximum ethanol tolerance level of the yeast.

Acetic acid also impacts growth of the cells, decreasing specific growth rate and biomass formation ${ }^{41}$. A $20 \%$ reduction in biomass occurred when $1 \mathrm{~g} / \mathrm{L}$ acetic acid was present at the onset of fermentation ${ }^{39}$. Fermentation rates were inhibited by $80 \%$ when $7.5 \mathrm{~g} / \mathrm{L}$ of acetic acid was present ${ }^{39}$. The impact of acetic acid is $\mathrm{pH}$ and strain dependent, with some Saccharomyces strains more sensitive to inhibition than others ${ }^{36}$. The presence of $L$. kunkeei in juice and ability to rapidly utilize fructose and produce acetic acid can account for the subsequent inhibition of fermentation. However, because the level of inhibition seen with acetic acid addition does not match that seen with L. kunkeei, it is likely that other mechanisms for the reduction in fermentation rate exist.

L. kunkeei is sensitive to $\mathrm{SO}_{2}$ and should be controllable by appropriate use of this antimicrobial agent. However, in our analyses of arrested fermentations in the 2013, 2014, and 2015 California vintages, we noticed a common microbial profile among problematic wines. Juice microbial profiling data generated by commercial laboratories showed low numbers of L. kunkeei in the original juice, but the wines also contained high levels of acetic acid bacteria, which we subsequently identified as Gluconobacter oxydans, G. cerinus, and Acetobacter pasteurianus. These three species of acetic acid bacteria when growing in juices make several oxidation products from glucose and fructose that form adjuncts with $\mathrm{SO}_{2}$, reducing its effective concentration ${ }^{42}$. We confirmed the ability of the acetic acid bacteria that we isolated from these arrested fermentations to tolerate typical usage levels of $\mathrm{SO}_{2}$, presumably via their well-known ability to produce compounds that will bind to $\mathrm{SO}_{2}{ }^{43}$. These bacteria are present in higher numbers in late harvest fruit and when higher incidence of rot is present in vineyards ${ }^{44}$, and levels may increase during winemaking operations such as cold soaks ${ }^{45}$. Thus, the combination of acetic acid bacteria and L. kunkeei is likely responsible for the appearance of the arrested fermentations. The titering out of added $\mathrm{SO}_{2}$ by the metabolic end products of the acetic acid bacteria enables rapid growth of L. kunkeei in the juice and subsequent inhibition of fermentation.

The environmental incentive for $\left[G A R^{+}\right]$prion induction by yeast in the presence of L. kunkeei and fermentation arrest. We discovered that many wine 
spoilage bacteria that lead to the inhibition of fermentation can fundamentally alter the metabolic state of Saccharomyces through the induction of prions ${ }^{46}$. The term "prion" is used to describe a biological situation in which the conformational form of a protein or protein complex is heritable, meaning that subsequent progeny will express the phenotype (Figure 2$)^{47}$. The central dogma states that phenotypes or the traits of organisms are due to the combined action of proteins that are encoded by the DNA. The presence or absence of the trait is directly correlated with the presence or absence of the required protein activities, which, in turn, is directly correlated with the presence of the gene in the genome.

In some cases, however, a protein can exist in more than one conformational state and these different states lead to different expressed traits or phenotypes within the cell. In this case, there is only one gene, but the protein product of that gene can lead to different traits depending upon its conformation within the cytoplasm. Under some circumstances, the conformational state of the protein can be inherited by progeny cells. When this occurs, the mode of inheritance is called a prion or prion-like mechanism ${ }^{48}$. The existence of prion-like modes of inheritance of phenotypic traits enables the population to sample a phenotype before making the commitment to a mutational change in the genome ${ }^{49}$.

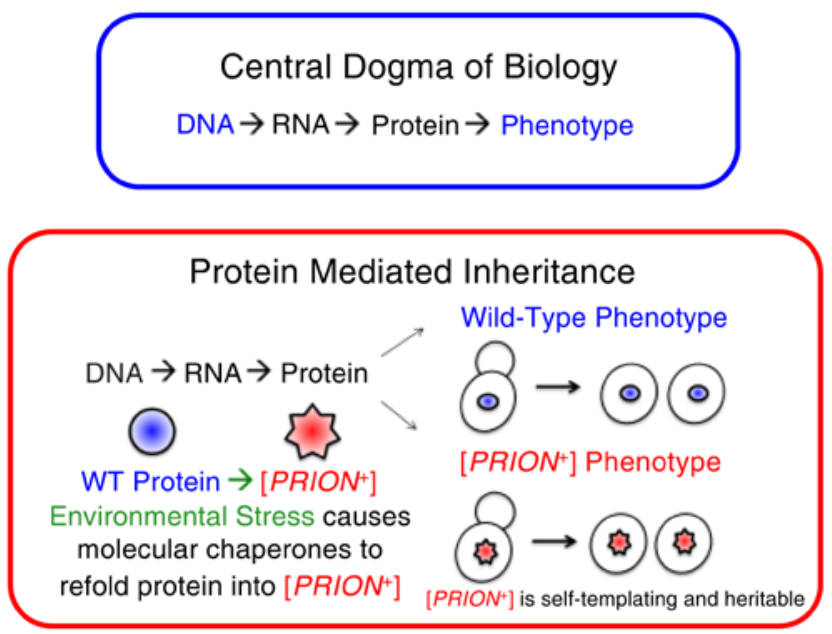

Figure 2 The mechanism of protein-based inheritance. The central dogma of DNA makes RNA makes protein is presented with cellular traits or phenotypes due to the expression of specific proteins. In the case of a prion, a protein may exist in more than one conformational state or form with each form conferring a different trait or phenotype. The conformation is dictated by proteins called chaperones that fold the target proteins in specific ways. Prions are distinguished by having a conformation that is dominant in hybrid cells and that is inherited by progeny cells; progeny cells do not display the other wild-type (WT) phenotype or protein conformation unless "cured" of the prion.
The $\left[G A R^{+}\right]$prion alters the ability of the yeast cells to exclusively consume the hexose sugars glucose and fructose ${ }^{50}$. This prion alters the binding properties of regulatory proteins that normally suppress growth on other substrates in the presence of glucose and that target metabolism for the exclusive use of hexose sugars. In the prion conformation, cells can use substrates in addition to hexoses, and the inhibition of use of those compounds by glucose is eliminated.

Our data show that L. kunkeei can induce the formation of the $\left[G A R^{+}\right]$prion in wine strains of Saccharomyces under winemaking conditions. We inoculated a Chardonnay juice with a low population size of $L$. kunkeei in the absence of $\mathrm{SO}_{2}$ and obtained an arrested fermentation. We then plated the surviving yeast to determine if the prion had been induced. We also evaluated the level of induction across the yeast population. Roughly $40 \%$ of the yeast isolated were $\left[G A R^{+}\right]$, showing that the presence of L. kunkeei during fermentation can lead to prion induction ${ }^{50}$. We have also isolated yeasts displaying the $\left[G A R^{+}\right]$phenotype from commercial wines that have arrested fermentation again at frequencies less than $100 \%$ within the viable yeast population ${ }^{51}$. Thus, this prion is induced during grape juice fermentation and higher percentages of $\left[G A R^{+}\right]$yeasts can be found in wines arrested due to the presence of inhibitory bacteria.

Induction of the $\left[G A R^{+}\right]$prion leads to several metabolic changes in the yeast cells. The consumption of glucose and fructose is reduced, simultaneous use of other carbon sources such as galactose is enabled, cell surface composition (both plasma membrane and cell wall) is altered, transport and other cell membrane functions are altered, higher levels of amino acids are released by the cells, and cell viability is enhanced ${ }^{52}$. The yeast consume oxygen at lower rates, which is of benefit to bacteria, and the release of higher levels of amino acids is also advantageous to bacteria.

Why have the yeast evolved to respond to the presence of bacteria in this way? Clearly enhanced viability in the presence of inhibitory levels of acetic acid is beneficial to the survival of the yeast, but the levels of acetic acid produced are usually below a toxic level in the absence of ethanol. What is the benefit of use of alternative carbon sources in the presence of high concentrations of glucose and fructose? The answer to this question may be associated with the high mannitol production of L. kunkeei. Most strains of Saccharomyces can use mannitol as a carbon and energy source, but only in the presence of other substrates ${ }^{53}$. The utilization of 
mannitol necessitates the re-oxidation of mannitol to fructose. The enzyme mannitol dehydrogenase uses $\mathrm{NAD}^{+}$to convert mannitol back to fructose ${ }^{53}$ and in the process NADH is produced. Similar to the process outlined in Figure 1, this NADH must be reoxidized to $\mathrm{NAD}^{+}$for use of mannitol to continue within the cell, meaning that another substrate must be reduced so that metabolism can continue. The level of production of mannitol by L. kunkeei is noteworthy and 1 mole of mannitol is produced per mole of fructose catabolized for energy by the bacterium ${ }^{54}$. Based on analysis of acetic acid levels in juice, there may be on the order of 10 to $15 \mathrm{~g} / \mathrm{L}$ or more of mannitol formed during the rapid growth phase of $L$. kunkeei ${ }^{55}$. Because mannitol transport occurs via the same transporters for glucose and fructose and is competitive with uptake of those substrates ${ }^{56}$, the cells may have no choice but to also co-metabolize the environmental mannitol.

To test this idea, we evaluated the ability of [gar] and $\left[G A R^{+}\right]$cells to utilize mannitol in rich medium conditions (Figure 3). The $\left[G A R^{+}\right]$cells efficiently utilized the mannitol in the medium. Thus, the yeast rationale for inducing the $\left[G A R^{+}\right]$prion might be to manage usage of a mixed substrate environment. This metabolic change has other consequences for the cells in terms of reduction of fermentative capacity for sugar substrates, but likely helps the cell maintain cofactor balances and to continue metabolism at a reduced level rather than shut down metabolism completely.

In addition, the commercial strain EC1118 was shown to catabolize mannitol during Sauvignon blanc fermentation, but this was observed only in a single vintage ${ }^{57}$. In other vintages, the authors noted that mannitol instead appeared to be made by the yeast. Mannitol can also be made by plants directly from photosynthesis and its production is thought to be associated with stress to the plants. Infection of grapevines by Uncinula necator, the causative agent of powdery mil-

Growth of [GAR+] and gar- strains of UCD932 on mannitol in the presence of glucosamine $(0.05 \%)$

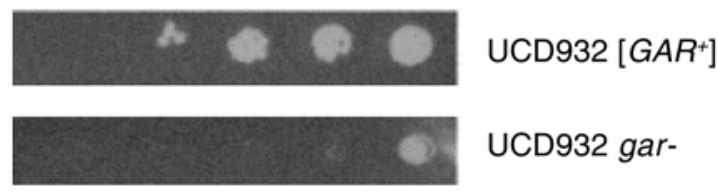

Figure 3 Strains carrying the $\left[G A R^{+}\right]$prion are able to use mannitol as compared to their [gar] controls. Cells of UCD932 induced (UCD932 [GAR+]) or not induced (UCD932gar) for the prion were plated on rich medium (yeast extract peptone) in the presence of glucosamine $(0.05 \%)$ with mannitol $(2 \%)$ as the sole carbon and energy source. Samples were processed as described in reference 45. dew, resulted in mannitol being produced in the leaves from photosynthesis ${ }^{58}$. Thus, mannitol exists in the fermentation environment, will be a competitive inhibitor of glucose and fructose uptake, and, if not consumed, may negatively impact yeast metabolism, because accumulation of mannitol has been shown to be inhibitory to fermentation ${ }^{59}$. Mannitol is synthesized by yeast and fungi as a protectant against oxidative damage, and when taken up by cells, associates with cell components in a form that is not readily extractable ${ }^{60}$.

The biological impetus for induction of the $\left[G A R^{+}\right]$ prion may be to metabolize an alternative substrate present in the fermentation. This adaptation to the presence of mixed substrates that can enter the cell via the glucose/fructose transporter system may also explain why only a fraction of the population induces the prion during fermentation. As the prion is induced and cells consume an alternative substrate such as mannitol, the levels of that alternative substrate in the fermentation will drop. This decrease of alternative substrate upon induction of the prion likely limits the fraction of the population that will eventually induce the prion based upon starting levels of the mixed substrates. This strategy assures a heterogeneous population of Saccharomyces with the level of $\left[G A R^{+}\right]$induction tailored to the level of the bacteria present and the synthesis of the alternative substrate.

We have also observed that induction of the $\left[G A R^{+}\right]$ prion leads to sustained viability of the yeast cells in the fermentation ${ }^{61}$. The changes in cell surface composition that accompany induction of the prion make the cell more resistant to the accumulation of toxic substances during the fermentation, thereby assuring survival of a subset of the population if environmental stress remains unabated.

\section{Outcomes}

The ability of L. kunkeei to lead to arrest of wine fermentations and the importance of this organism in bee and bee colony health are well established. Researchers have proposed enhancing the antimicrobial activity of L. kunkeei to combat CCD ${ }^{62}$. Such efforts could prove disastrous to the wine industry because modified strains will be vectored by bees to vineyards. The creation of super strains of yeast able to resist bacterial arrest has been proposed for the wine industry ${ }^{63}$. This could be equally as devastating to agricultural industries reliant on bees for pollination. Likewise, the grape industry should reconsider use of any chemical agents that would negatively impact hive health. The discovery of the mechanisms by which L. kunkeei 
inhibits yeast fermentation may enable other more sustainable practices for control of this organism within the winery. L. kunkeei can be controlled by use of $\mathrm{SO}_{2}$ at crush, but the utility of $\mathrm{SO}_{2}$ is dependent upon the $\mathrm{pH}$ of the juice and the presence of other microorganisms that produce $\mathrm{SO}_{2}$-binding compounds. Members of the acetic acid bacteria are prodigious producers of metabolites that reduce the concentration of the free form of $\mathrm{SO}_{2}$, and we have found these organisms in conjunction with $L$. kunkeei in arrested fermentations. Higher than typical levels of $\mathrm{SO}_{2}$ may need to be added in these circumstances. While L. kunkeei is vectored by bees, the acetic acid bacteria appear to be increasing due to the practice of late harvest and the incidence of rot in the vineyard, both of which are independent of bee vectoring. Cluster sorting at crush to reduce the numbers of acetic acid bacteria may also be of benefit. However, no solution should be considered that runs the risk of negatively impacting bee and hive health.

Acknowledgments: The research presented in this article was funded by the American Vineyard Foundation and by the Paul Monk Scholarship of Lallemand Inc. The authors also thank our winery cooperators for samples of arrested wine and for sharing microbial profiling data.

\section{References and Footnotes}

1. Boulton RB, Singleton VL, Bisson LF and Kunkee RE. 1996. Principles and Practices of Winemaking. Chapman \& Hall, New York; Edwards CG, Haag KM, Collins MD, Hutson RA and Huang YC. 1998. Lactobacillus kunkeei sp. nov.: A spoilage organism associated with grape juice fermentations. J Appl Microbiol 84:698-702; Edwards CG, Reynolds AC, Rodriguez AV, Semon, MJ and Mills JM. 1999. Implication of acetic acid in the induction of slow/stuck grape juice fermentation and inhibition of yeast by Lactobacillus sp. Am J Enol Vitic 50:204-210.

2. Vásquez A, Forsgren E, Fries I, Paxton RJ, Flaberg E, Szekely $\mathrm{L}$ and Olofsson TC. 2012. Symbionts as major modulators of insect health: lactic acid bacteria and honeybees. PLoS ONE 7:e33188. doi:10.1371/journal.pone.0033188; Anderson KE, Sheehan TH, Mott BM, Maes P, Snyder L, Schwan MR, Walton A, Jones BM and Corby-Harris V. 2013. Microbial ecology of the hive and pollination landscape: Bacterial associates from floral nectar, the alimentary tract and stored food of honey bees (Apis mellifera). PLoS ONE 8: e83125. doi:10.1371/journal.pone.0083125; Corby-Harris V, Maes P and Anderson KE. 2014. The bacterial communities associated with honey bee (Apis mellifera) foragers. PLoS ONE 9:e95056. doi:10.1371/journal.pone.0095056; Olofsson TC, Butler È, Markowicz P, Lindholm C, Larsson $\mathrm{L}$ and Vásquez A. 2014. Lactic acid bacterial symbionts in honeybees - an unknown key to honey's antimicrobial and therapeutic activities. Int Wound J doi: 10.1111/iwj.12345; Moran NA. 2015. Genomics of the honey bee microbiome. Curr Opinion Insct Sci 10:22-28.
3. Huang YC, Edwards CG, Peterson JC and Haag KM. 1996. Relationship between sluggish fermentations of grape juice and the antagonism of yeast by lactic acid bacteria. Am J Enol Vitic 47:1-10; Osborne JP and Edwards CG. 2005. Bacteria important during winemaking. Adv Food Nutr Res 50:139-177.

4. Huang YC, Edwards CG, Peterson JC and Haag KM. 1996. Relationship between sluggish fermentations of grape juice and the antagonism of yeast by lactic acid bacteria. Am J Enol Vitic 47:1-10; Edwards CG, Reynolds AC, Rodriguez AV, Semon, MJ and Mills JM. 1999. Implication of acetic acid in the induction of slow/stuck grape juice fermentation and inhibition of yeast by Lactobacillus sp. Am J Enol Vitic 50:204-210.

5. Edwards CG, Haag KM, Collins MD, Hutson RA and Huang YC. 1998. Lactobacillus kunkeei sp. nov.: a spoilage organism associated with grape juice fermentations. J Appl Microbiol 84:698-702.

6. Bae S, Fleet GH and Heard GM. 2006. Lactic acid bacteria associated with wine grapes from several Australian vineyards. J Appl Microbiol 100:712-727.

7. Boulton RB, Singleton VL, Bisson LF and Kunkee RE. 1996. Principles and Practices of Winemaking. Chapman \& Hall, New York; Edwards CG, Reynolds AC, Rodriguez AV, Semon, MJ and Mills JM. 1999. Implication of acetic acid in the induction of slow/stuck grape juice fermentation and inhibition of yeast by Lactobacillus sp. Am J Enol Vitic 50: 204-210; Osborne JP and Edwards CG. 2005. Bacteria important during winemaking. Adv Food Nutr Res 50:139-177; Bae S, Fleet GH and Heard GM. 2006. Lactic acid bacteria associated with wine grapes from several Australian vineyards. J Appl Micriobiol 100:712-727.

8. Tajabadi N, Mardan M, Manap MYA, Shuhuimi M, Meimandipour A and Nateghi L. 2011. Detection and identification of Lactobacillus bacteria found in the honey stomach of the giant honeybee Apis dorsata. Apidologie 42:642-649; Anderson KE, Sheehan TH, Mott BM, Maes P, Snyder L, Schwan MR, Walton A, Jones BM and Corby-Harris V. 2013. Microbial ecology of the hive and pollination landscape: Bacterial associates from floral nectar, the alimentary tract and stored food of honey bees (Apis mellifera). PLoS ONE 8:e83125. doi:10.1371/journal.pone.0083125; Moran NA. 2015. Genomics of the honey bee microbiome. Curr Opinion Insct Sci 10:22-28; Tamarit D, Ellegaard KM, Wikander J, Olofsson T, Vásquez A and Andersson SGE. 2015. Functionally structured genome in Lactobacillus kunkeei colonizing the honey crop and food products of honeybees and stingless bees. Genome Biol Evol 7:1455-1463.

9. Olofsson TC and Vásquez A. 2008. Detection and identification of a novel lactic acid bacterial flora within the honey stomach of the honeybee Apis mellifera. Curr Microbiol 57:356-363; Anderson KE, Sheehan TH, Eckholm BJ, Mott BM and DeGrandi-Hoffman G. 2011. An emerging paradigm of colony health: microbial balance of the honey bee and hive. Insect Soc 58:431-444; Wu M, Sugimura Y, Taylor D and Yoshiyama M. 2013. Honeybee gastrointestinal bacteria for novel and sustainable disease control strategies. J Devel Sust Agric 8:85-90; Yoshiyama M, Wu M, Sugimura Y, Takaya N, Kimoto-Nira H and Suzuki C. 2013. Inhibition of Paenibacillus larvae by lactic acid bacteria isolated from fermented materials. J Invert Pathol 112:62-67; Moran 
NA. 2015. Genomics of the honey bee microbiome. Curr Opinion Ins Sci 10:22-28.

10. Watanabe ME. 2008. Colony collapse disorder: many suspects, no smoking gun. BioSci 58:384-388; Forsgren E, Olofsson TC, Vásquez A, and Fries I. 2010. Novel lactic acid bacteria inhibiting Paenibacillus larvae in honey bee larvae. Apidologie 42:99-108; Mullin CA, Frazier M, Frazier JL, Ashcraft S, Simonds R, vanEngelsdorp D and Pettis JS. 2010. High levels of miticides and agrochemicals in North American apiaries: implications for honey bee health. PLoS ONE 5:e9754. doi:10.1371/journal.pone.0009754; Anderson KE, Sheehan TH, Eckholm BJ, Mott BM and DeGrandi-Hoffman G. 2011. An emerging paradigm of colony health: microbial balance of the honey bee and hive. Insect Soc 58:431-444.

11. Olofsson TC and Vásquez A. 2008. Detection and identification of a novel lactic acid bacterial flora within the honey stomach of the honeybee Apis mellifera. Curr Microbiol 57:356-363; Ahn JH, Hong IP, Bok JI, Kim BY, Song J and Weon HY. 2012. Pyrosequencing analysis of the bacterial community in the guts of honey bees Apis cerana and Apis mellifera in Korea. J Microbiol 50:735-745;Tajabadi N, Mardan M, Manap MYA, Shuhuimi M, Meimandipour A and Nateghi L. 2011. Detection and identification of Lactobacillus bacteria found in the honey stomach of the giant honeybee Apis dorsata. Apidologie 42:642-649; Vásquez A, Forsgren E, Fries I, Paxton RJ, Flaberg E, Szekely L and Olofsson TC. 2012. Symbionts as major modulators of insect health: lactic acid bacteria and honeybees. PLoS ONE 7:e33188. doi:10.1371/journal.pone.0033188; Moran NA. 2015. Genomics of the honey bee microbiome. Curr Opinion Insct Sci 10:22-28; Tamarit D, Ellegaard KM, Wikander J, Olofsson T, Vásquez A and Andersson SGE. 2015. Functionally structured genome in Lactobacillus kunkeei colonizing the honey crop and food products of honeybees and stingless bees. Genome Biol Evol 7:1455-1463.

12. Anderson KE, Sheehan TH, Eckholm BJ, Mott BM and DeGrandi-Hoffman G. 2011. An emerging paradigm of colony health: microbial balance of the honey bee and hive. Insect Soc 58:431-444.

13. Olofsson TC and Vásquez A. 2008. Detection and identification of a novel lactic acid bacterial flora within the honey stomach of the honeybee Apis mellifera. Curr Microbiol 57:356-363; Forsgren E, Olofsson TC, Vásquez A, and Fries I. 2010. Novel lactic acid bacteria inhibiting Paenibacillus larvae in honey bee larvae. Apidologie 42:99-108; Anderson KE, Sheehan TH, Eckholm BJ, Mott BM and DeGrandiHoffman G. 2011. An emerging paradigm of colony health: microbial balance of the honey bee and hive. Insect Soc 58:431-444.

14. Anderson KE, Sheehan TH, Eckholm BJ, Mott BM and DeGrandi-Hoffman G. 2011. An emerging paradigm of colony health: microbial balance of the honey bee and hive. Insect Soc 58:431-444; Martinson VG, Danforth BN, Minckley RL, Rueppell 0, Tingek S and Moran NA. 2011. A simple and distinctive microbiota associated with honey bees and bumble bee. Molec Ecol 20:619-628; Ahn JH, Hong IP, Bok JI, Kim BY, Song J and Weon HY. 2012. Pyrosequencing analysis of the bacterial community in the guts of honey bees Apis cerana and Apis mellifera in Korea. J Microbiol 50:735-745; Vásquez A, Forsgren E, Fries I, Paxton RJ, Flaberg E, Szekely
L and Olofsson TC. 2012. Symbionts as major modulators of insect health: lactic acid bacteria and honeybees. PLoS ONE 7:e33188. Butler É, Alsterfjord M, Olofsson TC, Karlsson C, Malmström J and Vásquez A. 2013. Proteins of novel lactic acid bacteria from Apis mellifera: an insight into the production of known extra-cellular proteins during microbial stress. BMC Microbiol 13:235; Corby-Harris V, Maes P and Anderson KE. 2014. The bacterial communities associated with honey bee (Apis mellifera) foragers. PLoS ONE 9:e95056. doi:10.1371/journal.pone.0095056; Kwong WK, Engel P, Koch H and Moran NA. 2014. Genomics and host specialization of honey bee and bumble bee gut symbionts. Proc Natl Acad Sci USA 111:11509-11514; Olofsson TC, Butler È, Markowicz P, Lindholm C, Larsson L and Vásquez A. 2014. Lactic acid bacterial symbionts in honeybees - an unknown key to honey's antimicrobial and therapeutic activities. Int Wound J doi: 10.1111/iwj.12345; Tamarit D, Ellegaard KM, Wikander J, Olofsson T, Vásquez A and Andersson SGE. 2015. Functionally structured genome in Lactobacillus kunkeei colonizing the honey crop and food products of honeybees and stingless bees. Genome Biol Evol 7:1455-1463.

15. Olofsson TC and Vásquez A. 2008. Detection and identification of a novel lactic acid bacterial flora within the honey stomach of the honeybee Apis mellifera. Curr Microbiol 57:356-363; Forsgren E, Olofsson TC, Vásquez A, and Fries I. 2010. Novel lactic acid bacteria inhibiting Paenibacillus larvae in honey bee larvae. Apidologie 42:99-108; Anderson KE, Sheehan TH, Eckholm BJ, Mott BM and DeGrandi-Hoffman G. 2011. An emerging paradigm of colony health: microbial balance of the honey bee and hive. Insect Soc 58:431-444; Butler É, Alsterfjord M, Olofsson TC, Karlsson C, Malmström J and Vásquez A. 2013. Proteins of novel lactic acid bacteria from Apis mellifera: an insight into the production of known extra-cellular proteins during microbial stress. BMC Microbiol 13:235; Endo A and Salminen S. 2013. Honeybees and beehives are rich sources for fructophilic lactic acid bacteria. Sys Appl Microbiol 36:444-448; Wu M, Sugimura Y, Taylor D and Yoshiyama M. 2013. Honeybee gastrointestinal bacteria for novel and sustainable disease control strategies. J Devel Sust Agric 8:85-90; Yoshiyama M, Wu M, Sugimura Y, Takaya N, Kimoto-Nira H and Suzuki C. 2013. Inhibition of Paenibacillus larvae by lactic acid bacteria isolated from fermented materials. J Invert Pathol 112:62-67; Moran NA. 2015. Genomics of the honey bee microbiome. Curr Opinion Insct Sci 10:22-28.

16. Forsgren E, Olofsson TC, Vásquez A, and Fries I. 2010. Novel lactic acid bacteria inhibiting Paenibacillus larvae in honey bee larvae. Apidologie 42:99-108; Butler É, Alsterfjord M, Olofsson TC, Karlsson C, Malmström J and Vásquez A. 2013. Proteins of novel lactic acid bacteria from Apis mellifera: an insight into the production of known extra-cellular proteins during microbial stress. BMC Microbiol 13:235; Endo A and Salminen S. 2013. Honeybees and beehives are rich sources for fructophilic lactic acid bacteria. Sys Appl Microbiol 36:444-448; Yoshiyama M, Wu M, Sugimura Y, Takaya N, Kimoto-Nira H and Suzuki C. 2013. Inhibition of Paenibacillus larvae by lactic acid bacteria isolated from fermented materials. J Invert Pathol 112:62-67.

17. Vásquez A, Forsgren E, Fries I, Paxton RJ, Flaberg E, Szekely $\mathrm{L}$ and Olofsson TC. 2012. Symbionts as major modulators of insect health: lactic acid bacteria and honeybees. 
PLoS ONE 7:e33188. doi:10.1371/journal.pone.0033188; Olofsson TC, Butler È, Markowicz P, Lindholm C, Larsson L and Vásquez A. 2014. Lactic acid bacterial symbionts in honeybees - an unknown key to honey's antimicrobial and therapeutic activities. Int Wound J doi: 10.1111/iwj.12345.

18. Vásquez A, Forsgren E, Fries I, Paxton RJ, Flaberg E, Szekely $\mathrm{L}$ and Olofsson TC. 2012. Symbionts as major modulators of insect health: lactic acid bacteria and honeybees. PLoS ONE 7:e33188. doi:10.1371/journal.pone.0033188.

19. Forsgren E, Olofsson TC, Vásquez A, and Fries I. 2010. Novel lactic acid bacteria inhibiting Paenibacillus larvae in honey bee larvae. Apidologie 42:99-108; Anderson KE, Sheehan TH, Eckholm BJ, Mott BM and DeGrandi-Hoffman G. 2011. An emerging paradigm of colony health: microbial balance of the honey bee and hive. Insect Soc 58:431-444; Butler É, Alsterfjord M, Olofsson TC, Karlsson C, Malmström J and Vásquez A. 2013. Proteins of novel lactic acid bacteria from Apis mellifera: an insight into the production of known extra-cellular proteins during microbial stress. BMC Microbiol 13:235; Vásquez A, Forsgren E, Fries I, Paxton RJ, Flaberg E, Szekely L and Olofsson TC. 2012. Symbionts as major modulators of insect health: lactic acid bacteria and honeybees. PLoS ONE 7:e33188. doi:10.1371/journal. pone.0033188; Wu M, Sugimura Y, Taylor D and Yoshiyama M. 2013. Honeybee gastrointestinal bacteria for novel and sustainable disease control strategies. J Devel Sust Agric 8:85-90; Yoshiyama M, Wu M, Sugimura Y, Takaya N, Kimoto-Nira H and Suzuki C. 2013. Inhibition of Paenibacillus larvae by lactic acid bacteria isolated from fermented materials. J Invert Pathol 112:62-67; Olofsson TC, Butler È, Markowicz P, Lindholm C, Larsson L and Vásquez A. 2014. Lactic acid bacterial symbionts in honeybees - an unknown key to honey's antimicrobial and therapeutic activities. Int Wound J 13:668-679; Moran NA. 2015. Genomics of the honey bee microbiome. Curr Opinion Insct Sci 10:22-28.

20. Olofsson TC and Vásquez A. 2008. Detection and identification of a novel lactic acid bacterial flora within the honey stomach of the honeybee Apis mellifera. Curr Microbiol 57:356-363; Butler É, Alsterfjord M, Olofsson TC, Karlsson C, Malmström J and Vásquez A. 2013. Proteins of novel lactic acid bacteria from Apis mellifera: an insight into the production of known extra-cellular proteins during microbial stress. BMC Microbiol 13:235; Olofsson TC, Butler È, Markowicz P, Lindholm C, Larsson L and Vásquez A. 2014. Lactic acid bacterial symbionts in honeybees - an unknown key to honey's antimicrobial and therapeutic activities. Int Wound J 13:668-679; Moran NA. 2015. Genomics of the honey bee microbiome. Curr Opinion Insct Sci 10:22-28.

21. Olofsson TC and Vásquez A. 2008. Detection and identification of a novel lactic acid bacterial flora within the honey stomach of the honeybee Apis mellifera. Curr Microbiol 57:356-363; Anderson KE, Sheehan TH, Eckholm BJ, Mott BM and DeGrandi-Hoffman G. 2011. An emerging paradigm of colony health: microbial balance of the honey bee and hive. Insect Soc 58:431-444; Ahn JH, Hong IP, Bok JI, Kim BY, Song J and Weon HY. 2012. Pyrosequencing analysis of the bacterial community in the guts of honey bees Apis cerana and Apis mellifera in Korea. J Microbiol 50:735-745; Vásquez A, Forsgren E, Fries I, Paxton RJ, Flaberg E, Szekely $\mathrm{L}$ and Olofsson TC. 2012. Symbionts as major modulators of insect health: lactic acid bacteria and honeybees. PLoS ONE 7:e33188. doi:10.1371/journal.pone.0033188; Anderson
KE, Sheehan TH, Mott BM, Maes P, Snyder L, Schwan MR, Walton A, Jones BM and Corby-Harris V. 2013. Microbial ecology of the hive and pollination landscape: Bacterial associates from floral nectar, the alimentary tract and stored food of honey bees (Apis mellifera). PLoS ONE 8: e83125. doi:10.1371/journal.pone.0083125; Endo A and Salminen S. 2013. Honeybees and beehives are rich sources for fructophilic lactic acid bacteria. Sys Appl Microbiol 36:444-448; Wu M, Sugimura Y, Taylor D and Yoshiyama M. 2013. Honeybee gastrointestinal bacteria for novel and sustainable disease control strategies. J Devel Sust Agric 8:85-90; Corby-Harris V, Maes P and Anderson KE. 2014. The bacterial communities associated with honey bee (Apis mellifera) foragers. PLoS ONE 9:e95056. doi:10.1371/ journal.pone.0095056; Tamarit D, Ellegaard KM, Wikander J, Olofsson T, Vásquez A and Andersson SGE. 2015. Functionally structured genome in Lactobacillus kunkeei colonizing the honey crop and food products of honeybees and stingless bees. Genome Biol Evol 7:1455-1463.

22. Forsgren E, Olofsson TC, Vásquez A, and Fries I. 2010. Novel lactic acid bacteria inhibiting Paenibacillus larvae in honey bee larvae. Apidologie 42:99-108; Yoshiyama M, Wu M, Sugimura Y, Takaya N, Kimoto-Nira H and Suzuki C. 2013. Inhibition of Paenibacillus larvae by lactic acid bacteria isolated from fermented materials. J Invert Pathol 112:62-67.

23. Olofsson TC and Vásquez A. 2008. Detection and identification of a novel lactic acid bacterial flora within the honey stomach of the honeybee Apis mellifera. Curr Microbiol 57:356-363.

24. Yoshiyama M, Wu M, Sugimura Y, Takaya N, Kimoto-Nira $\mathrm{H}$ and Suzuki C. 2013. Inhibition of Paenibacillus larvae by lactic acid bacteria isolated from fermented materials. J Invert Pathol 112:62-67.

25. Forsgren E, Olofsson TC, Vásquez A, and Fries I. 2010. Novel lactic acid bacteria inhibiting Paenibacillus larvae in honey bee larvae. Apidologie 42:99-108; Vásquez A, Forsgren E, Fries I, Paxton RJ, Flaberg E, Szekely L and Olofsson TC. 2012. Symbionts as major modulators of insect health: lactic acid bacteria and honeybees. PLoS ONE 7:e33188. doi:10.1371/journal.pone.0033188.

26. Olofsson TC and Vásquez A. 2008. Detection and identification of a novel lactic acid bacterial flora within the honey stomach of the honeybee Apis mellifera. Curr Microbiol 57:356-363; Butler É, Alsterfjord M, Olofsson TC, Karlsson C, Malmström J and Vásquez A. 2013. Proteins of novel lactic acid bacteria from Apis mellifera: an insight into the production of known extra-cellular proteins during microbial stress. BMC Microbiol 13:235; Yoshiyama M, Wu M, Sugimura Y, Takaya N, Kimoto-Nira H and Suzuki C. 2013. Inhibition of Paenibacillus larvae by lactic acid bacteria isolated from fermented materials. J Invert Pathol 112:62-67; Olofsson TC, Butler È, Markowicz P, Lindholm C, Larsson L and Vásquez A. 2014. Lactic acid bacterial symbionts in honeybees - an unknown key to honey's antimicrobial and therapeutic activities. Int Wound J 13:668-679; Moran NA. 2015. Genomics of the honey bee microbiome. Curr Opinion Insct Sci 10:22-28.

27. Olofsson TC, Butler È, Markowicz P, Lindholm C, Larsson L and Vásquez A. 2014. Lactic acid bacterial symbionts in 
honeybees - an unknown key to honey's antimicrobial and therapeutic activities. Int Wound J 13:668-679.

28. Butler É, Alsterfjord M, Olofsson TC, Karlsson C, Malmström J and Vásquez A. 2013. Proteins of novel lactic acid bacteria from Apis mellifera: an insight into the production of known extra-cellular proteins during microbial stress. BMC Microbiol 13:235; Yoshiyama M, Wu M, Sugimura Y, Takaya N, Kimoto-Nira H and Suzuki C. 2013. Inhibition of Paenibacillus larvae by lactic acid bacteria isolated from fermented materials. J Invert Pathol 112:62-67.

29. Boulton RB, Singleton VL, Bisson LF and Kunkee RE. 1996. Principles and Practices of Winemaking. Chapman \& Hall, New York; Edwards CG, Haag KM, Collins MD, Hutson RA and Huang YC. 1998. Lactobacillus kunkeei sp. nov.: A spoilage organism associated with grape juice fermentations. J Appl Microbiol 84:698-702; Endo A, Irisawa T, FutagawaEndo Y, Takano K, du Toit M, Okada S and Dicks LMT. 2012. Characterization and emended description of Lactobacillus kunkeei as a fructophilic lactic acid bacterium. Int J Sys Ecol Microbiol 62:500-504.

30. Endo A, Futagawa-Endo Y and Dicks LMT. 2009. Isolation and characterization of fructophilic lactic acid bacteria from fructose-rich niches. Sys Appl Microbiol 32:593600; Endo A, Irisawa T, Futagawa-Endo Y, Takano K, du Toit M, Okada S and Dicks LMT. 2012. Characterization and emended description of Lactobacillus kunkeei as a fructophilic lactic acid bacterium. Int J Sys Ecol Microbiol 62:500-504. And see the following reference for a discussion of the evolution of mannitol production in lactic acid bacteria: Grobben GJ, Peters SWPG, Wisselink HW, Weusthuis RA, Hoenfnagel MHN, Hugenholtz J and Eggink G. 2001. Spontaneous formation of a mannitol-producing variant of Leuconostoc pseudomesenteroides grown in the presence of fructose. Appl Environ Microbiol 67:2867-2870.

31. Endo A, Irisawa T, Futagawa-Endo Y, Takano K, du Toit M, Okada S and Dicks LMT. 2012. Characterization and emended description of Lactobacillus kunkeei as a fructophilic lactic acid bacterium. Int J Sys Ecol Microbiol 62:500-504.

32. Endo A, Futagawa-Endo Y and Dicks LMT. 2009. Isolation and characterization of fructophilic lactic acid bacteria from fructose-rich niches. Sys Appl Microbiol 32:593-600; Endo A and Salminen S. 2013. Honeybees and beehives are rich sources for fructophilic lactic acid bacteria. Sys Appl Microbiol 36:444-448.

33. Huang YC, Edwards CG, Peterson JC and Haag KM. 1996. Relationship between sluggish fermentations of grape juice and the antagonism of yeast by lactic acid bacteria. Am J Enol Vitic 47:1-10.

34. Edwards CG, Haag KM, Collins MD, Hutson RA and Huang YC. 1998. Lactobacillus kunkeei sp. nov.: A spoilage organism associated with grape juice fermentations. J Appl Microbiol 84:698-702.

35. Phowchinda O, Délia-Dupuy ML and Strehaiano. 1995. Effects of acetic acid on growth and fermentative activity of Saccharomyces cerevisiae. Biotech Letts 17:237-242. Edwards CG, Reynolds AC, Rodriguez AV, Semon, MJ and Mills JM. 1999. Implication of acetic acid in the induction of slow/stuck grape juice fermentation and inhibition of yeast by Lactobacillus sp. Am J Enol Vitic 50:204-210; Eg- linton JM and Henschke PA. 1999. Restarting incomplete fermentations: the effect of high concentrations of acetic acid. Aust J Grape Wine Res 5:71-78; Osborne JP and Edwards CG. 2005. Bacteria important during winemaking. Adv Food Nutr Res 50:139-177.

36. Edwards CG, Reynolds AC, Rodriguez AV, Semon, MJ and Mills JM. 1999. Implication of acetic acid in the induction of slow/stuck grape juice fermentation and inhibition of yeast by Lactobacillus sp. Am J Enol Vitic 50:204-210.

37. Sponholz WR. 1993. Wine spoilage by microorganisms. In Wine Microbiology and Biotechnology. GH Fleet (ed.) p 395-420. Harwood Academic Publishers, Chur, Switzerland.

38. Pampulha ME and Loureiro V. 1989. Interaction of the effects of acetic acid and ethanol on inhibition of fermentation in Saccharomyces cerevisiae. Biotech Letts 4:269-274; Pampulha ME and Loureiro-Dias MC. 1989. Combined effect of acetic acid, $\mathrm{pH}$ and ethanol on intracellular $\mathrm{pH}$ of fermenting yeast. Appl Microbial Biotech 31:547-550; Pampulha ME and Loureiro-Dias MC. 1990. Activity of glycolytic enzymes of Saccharomyces cerevisiae in presence of acetic acid. Appl Microbial Biotech 34:375-380.

39. Phowchinda O, Délia-Dupuy ML and Strehaiano. 1995. Effects of acetic acid on growth and fermentative activity of Saccharomyces cerevisiae. Biotech Letts 17:237-242.

40. Pampulha ME and Loureiro V. 1989. Interaction of the effects of acetic acid and ethanol on inhibition of fermentation in Saccharomyces cerevisiae. Biotech Letts 4:269-274.

41. Phowchinda O, Délia-Dupuy ML and Strehaiano. 1995. Effects of acetic acid on growth and fermentative activity of Saccharomyces cerevisiae. Biotech Letts 17:237-242; Pampulha ME and Loureiro-Dias MC. 2000. Energetics of the effect of acetic acid on growth of Saccharomyces cerevisiae. FEMS Microbiol Letts 184:69-72.

42. Barbe JC, de Revel G, Joyeux A, Bertrand A and LonvaudFunel A. 2001. Role of botrytized grape micro-organisms in $\mathrm{SO}_{2}$ binding phenomena. J Appl Micro 90:34-42; Barbe JC. 2002. Gluconic acid, its lactones, and $\mathrm{SO}_{2}$ binding phenomena in musts from botrytized grapes. J Ag Food Chem 50:6408-6412; Du Toit WJ and Lambrechts MG. 2002. The enumeration and identification of acetic acid bacteria from South African red wine fermentations. Int J Food Microbiol 74:57-64.

43. Luo Y. 2016. The Influence of Novel Species of Bacteria on Yeast Fermentation. Thesis, University of California, Davis.

44. Barbe JC, de Revel G, Joyeux A, Bertrand A and LonvaudFunel A. 2001. Role of botrytized grape micro-organisms in $\mathrm{SO}_{2}$ binding phenomena. J Appl Micro 90:34-42; Mas A, Torija MJ, González A, Poblet M and Guillamón JM. 2007. Acetic acid bacteria in oenology. Contrib Sci 3:511-521; Barata A, Malfeito-Ferreira M and Loureiro V. 2012. Changes in sour rotting grape berry microbiota during ripening and wine fermentation. Int J Food Microbiol 154:152-161; Martins G, Miot-Sertier C, Lauga B, Claisse 0, Lonvaud-Funel A, Soulas G and Masneuf-Pomarède I. 2012. Grape berry microbiota: impact of the ripening process and the farming system. Int J Food Microbiol 158:93-100.

45. Du Toit WJ and Lambrechts MG. 2002. The enumeration and identification of acetic acid bacteria from South African red wine fermentations. Int J Food Microbiol 74:57-64. 
46. Jarosz DF et al. 2014. Cross-kingdom chemical communication drives a heritable mutually beneficial prion-based transformation of metabolism. Cell 158:1083-1093; Walker GA, Hjelmeland A, Bokulich NA, Mills DA, Ebeler SE and Bisson LF. 2016. Impact of the [GAR+] prion on fermentation and bacterial population composition with Saccharomyces cerevisiae UCD932. Am J Enol Vitic 67:296-307.

47. Halfmann R, Alberti S and Lindquist S. 2010. Prions, protein homeostasis, and phenotypic diversity. Trends Cell Biol 20:125-133; Garcia DM and Jarosz DF. 2014. Rebels with a cause: molecular features and physiological consequences of yeast prions. FEMS Yeast Res 14:136-147.

48. Newby GA and Lindquist S. 2013. Blessings in disguise: biological benefits of prion-like mechanisms. Cell 23:251259; Garcia DM and Jarosz DF. 2014. Rebels with a cause: molecular features and physiological consequences of yeast prions. FEMS Yeast Res 14:136-147; Tuite M. 2015. Yeast prions: paramutation at the protein level? Sem Cell Devel Biol 44:51-61; Moosari B, Mousari B and Yang GF. 2016. Actin, membrane trafficking, and the control of prion induction, propagation and transmission in yeast. Traffic 17:5-20.

49. Wang J, Atolia E, Jua B, Savis Y, Escalante-Chong R and Springer M. 2015. Natural variation in preparation for nutrient depletion reveals a cost-benefit trade off. PLoS Biol 13:e1002041.doi:10.1371/journal.pbio.1002041; Yona AH, Frumkin I and Pilpel Y. 2015. A relay race on the evolutionary adaptation spectrum. Cell 163:549-559.

50. Brown JCS and Lindquist S. 2009. A heritable switch in carbon source utilization by an unusual yeast prion. Genes Develop 23:2320-2332.

51. Chardonnay grapes from the UCD vineyards were crushed and pressed and the juice used without $\mathrm{SO}_{2}$ addition. $\mathrm{A}$ culture of $L$. kunkeei grown in $10 \mathrm{~mL} 1 / 2 \mathrm{MRS}$ medium for 3 days to an $\mathrm{OD}_{600} \mathrm{~nm}$ of 0.4 to 0.6 was used to inoculate 12 gallons of the juice for an inoculation level of roughly 1,000 cells/mL in the juice. Twenty four hours later yeast EC1118 was inoculated into the fermentation. Fermentations were monitored for Brix daily. The control fermentation was complete within nine days. The fermentation inoculated with L. kunkeei was sluggish starting at a Brix level of 10, and arrested with a Brix value of 0.5 . Samples of yeast were taken from the fermentation after arrest, plated for isolation on $\mathrm{YPD}_{2 \%}$ glucose plates and 10 representative colonies were restreaked on $\mathrm{YPD}_{2 \% \text { glucose }}$ plates for purity. Overnight cultures of the individual isolates were used to subculture into fresh $\mathrm{YPD}_{2 \% \text { glucose }}$ liquid media and grown to early exponential phase $\left(0.4 \mathrm{OD}_{580}\right)$. They were then tested on GGM (Glycerol glucosamine medium) plates using 1:5 serial dilutions and scored as compared to wild-type EC1118 isolates.

52. Walker GA unpublished observations; Jarosz DF, Brown JCS, Walker GA, Datta MS, Ung WL, Lancaster AK, Rotem A, Chang A, Newby GA, Weitz DA, Bisson LF and Lindquist S. 2014. Cross-kingdom chemical communication drives a heritable mutually beneficial prion-based transformation of metabolism. Cell 158:1083-1093; Walker GA, Hjelmeland A, Bokulich NA, Mills DA, Ebeler SE and Bisson LF. 2016. Impact of the $[\mathrm{GAR}+]$ prion on fermentation and bacterial population composition with Saccharomyces cerevisiae UCD932. Am J Enol Vitic 67:296-307.

53. Quain DE and Boulton CA. 1987. Growth and metabolism of mannitol by strains of Saccharomyces cerevisiae. J Gen Microbiol 133:1675-1684; Watanabe Y, Takechi Y, Nagayama $\mathrm{K}$ and Tamai Y. 2006. Overexpression of Saccharomyces cerevisiae mannitol dehydrogenase gene (YEL070w) in glycerol synthesis-deficient $S$. cerevisiae mutant. Enz. Microbiol Tech 39:654-659.

54. Endo A, Futagawa-Endo Y and Dicks LMT. 2009. Isolation and characterization of fructophilic lactic acid bacteria from fructose-rich niches. Sys Appl Microbiol 32:593-600.

55. From reference 53, the molar ratio of fructose to mannitol production by L. kunkeei is 0.7 to 1.0 , likely depending upon the availability of co-substrates. In reference 41, Edwards et al cite an acetic acid production level of 4 to $5 \mathrm{~g} / \mathrm{L}$ for $L$. kunkeei. This is the equivalent of 0.067 to $0.083 \mathrm{M}$ of acetic acid. Assuming an equivalent production of mannitol, the level of mannitol present would be 12 to $15 \mathrm{~g} / \mathrm{L}$.

56. Maxwell WA and Spoerl E. 1971. Mannitol uptake by Saccharomyces cerevisiae. J Bacteriol 105:753-758.

57. Pinu FR, Edwards PJB, Gardner RC and Villas-Boas SG. 2014. Nitrogen and carbon assimilation by Saccharomyces cerevisiae during Sauvignon blanc juice fermentation, FEMS Yeast Res 14:1206-1222.

58. Brem S, Rast DM and Ruffner HP. 1986. Partitioning of photosynthate in leaves of Vitis vinifera infected with Uncinula necator or Plasmopora viticola. Phys Molec Plant Path 29:285-291.

59. Costenoble R, Adler L, Niklasson C and Linden G. 2003. Engineering of the metabolism of Saccharomyces cerevisiae for anaerobic production of mannitol. FEMS Yeast Res 3:17-25.

60. Shen B, Hohmann S, Jensen RG and Bohnert HJ. 1999. Roles of sugar alcohols in osmotic stress adaptation. Replacement of glycerol by mannitol and sorbitol in yeast. Plant Physiol 121:45-52; Ruijter GJG, Bax M, Patel H, Flitter SJ, van de Vondervoort PJI, de Vries RP, vanKuyk PA and Visser J. 2003. Mannitol is required for stress tolerance in Aspergillus niger conidiospores. Euk Cell 2:690-698.

61. Jarosz DF et al. 2014. Cross-kingdom chemical communication drives a heritable mutually beneficial prion-based transformation of metabolism. Cell 158:1083-1093.

62. Rangberg A, Mathiesen G, Andam GV and Diep BD. 2015. The paratransgenic potential of Lactobacillus kunkeei in the honey bee Apis mellifera. Beneficial Microbes 6:513-623.

63. Du Toit M and Pretorius S. 2000. Microbial spoilage and preservation of wine: using weapons from nature's own arsenal - A review. S Afr J Enol Vitic 21:74-96. 